\title{
Putting the Brakes on Gendered Mishaps during COVID-19 Pandemic: Safeguarding the Health and Rights of Women and Girls in Bangladesh
}

\author{
Zawad Ibn Farid*1, Isna Haque Sheoti ${ }^{2}$, Muhammad Awfa Islam ${ }^{3}$, Sawban Ibn Farid ${ }^{4}$ \\ ${ }^{1,3}$ Institute of Disaster Management and Vulnerability Studies, University of Dhaka, Dhaka-1000, Bangladesh \\ ${ }^{2}$ Department of Population Science, University of Dhaka, Dhaka-1000, Bangladesh \\ ${ }^{4}$ Department of International Relations, Jahangirnagar University, Dhaka-1000, Bangladesh
}

DOI: https://dx.doi.org/10.47772/IJRISS.2021.5304

\begin{abstract}
The surge of Covid-19 pandemic had forced the governments all around the world to declare lockdown and other preventive measures to limit the spread of the virus. Although the outcome of such initiatives has positively contributed towards communities, it has also taken a disproportionate toll on women and girls in terms of their health and rights. The finding of this study is premised upon the interpretation of information from different relevant secondary sources. This review article explores the situation of women and girls during Covid-19 in a developing country like Bangladesh. The findings of the study suggest that, women and girls are the worst sufferer of COVID-19 pandemic. The societal constructed gender roles along with historical inequality and systematic disenfranchisement have added to their vulnerability substantially during this dire time. Women and girls have suffered both socially i.e., domestic violence; economically i.e., unemployment; and physically i.e., unaddressed sexual and reproductive health needs. However, the article also suggests plausible solutions to overcome the undesirable situation through undertaking a holistic approach towards safeguarding the health and rights of women in Bangladesh. Measures like economic empowerment through stimulus package, social protection through safety net programs along with need based innovative interventions from government, non-government and private agencies are expected to put a break on the ongoing gendered mishaps and augment the position of women and girls in the society.
\end{abstract}

Keywords: COVID-19, Domestic violence, Gender, Women, Girls, Health rights.

\section{INTRODUCTION}

$\mathrm{T}$ he novel coronavirus disease (COVID-19) outbreak was first identified in China in December 2019, and the World Health Organization (WHO) declared the COVID-19 outbreak as a globally concerned public health emergency on January 30, 2020 (WHO, 2020a) and recognized as a worldwide pandemic on 11 March, 2020. This virus causes infectious disease, which transmits from person to person through everyday social contact. As a response to this pandemic, governments of worldwide had adopted lockdown, quarantine, and other preventive measures to prevent the spread of diseases (Farid, 2020). Until April 2020, 3.9 billion people in more than 100 countries or territories adopted lockdown and staying home measures for different period of time (BBC, 2020). Although infectious disease can affect everyone in the same way, sex and gender play a significant part in a biological disease's effect on a human being. The COVID-19 pandemic has a gendered effect on the health and well-being of men and women. Statistics worldwide have shown that men are more likely to die due to this disease than women for varying antibody reactions, hormones, genetics, and behavioral reasons (European Commission, 2020). Biological impacts are not the end consequences of a pandemic. It intersects with the broader social and systematic challenges, including health care, resources, vulnerabilities, access, participation, social position, and other factors (Farid, 2020).

Therefore, women are more likely to suffer from health, economic, and social consequences due to the COVID-19 pandemic (Tarlov, 2002). This worldwide public health emergency has the potential to magnify the existing inequalities on women and girls exponentially (Save the Children, 2020). This pandemic intensifies inequalities toward women as millions more girls and women losing their decision-making abilities about their families and their bodies and health (Power, 2020).

Primarily, women's reproductive health rights and related health concerns heighten during an emergency. This occurs due to the already fatigued health care system, disruption in supply chains, redirected resources, relocation of resources and priorities (United Nations, 2020; Viveiros \& Bonomi, 2020). Thus, women are not getting adequate medical facilities for reproductive health, such as; abortion and contraception. A country-wide lockdown has put a strain on closing the largest family planning services clinics in India and Nepal. In the Caribbean and in Latin America, it is estimated that more than 18 million women will lose regular access to contraceptives (Viveiros \& Bonomi, 2020). Moreover, women are a prominent part of non-salaried, parttime employment, self-employed and precarious employment (European Commission, 2020). For this reason, women have less earning, lower savings, and they will be most vulnerable during the COVID-19 situation. Women perform educational duties and unpaid care work in most countries around the world (European Commission, 2020). The lockdown measure will increase this burden as women have to take care of more out-of-school children and older persons at home (United 
Nations, 2020). Consequently, the economic position and household work burden of women is worsening in this situation.

Subsequently, women are also profoundly affected by other existing inequalities such as age, social origin, poverty, and disability. Gender inequalities will be more severe in countries with weak institutional capacity, fragility and conflict during this emergency period. Countries affected by (European Commission, 2020). This pandemic also has a devastating impact on girl children's long-term well-being and resilience. Their education, protective structure, family, and communities are suffering due to health and economic burden caused by the pandemic. (Plan International UK, 2020). Conclusively, the global health emergency adds fuel to women's already demeaning position and negatively affects every aspect of their life.

This pandemic has affected all aspects of women's life and increased violence against them. As per WHO \& HRP, violence against women is a violation of human rights rooted in gender inequality. This violence against women can result in serious injuries such as immense physical, mental, reproductive health and sexual problems including sexually transmitted disease like HIV, and unplanned pregnancies (WHO \& HRP, 2019; WHO, 2020b). Data from United States, United Kingdom, and China also suggest increasing domestic violence during the lockdown. The number of cases of domestic violence have tripled till February 2020 in Hubei Province compared to last year (WHO, 2020b). The largest United Nations charity of domestic violence, "Refugee," has reported a 700\% increase in domestic violence reports during lockdown period (Viveiros \& Bonomi, 2020). WHO reported in April 2020, calls received by European domestic violence hotlines have spiked almost 60 percent. The situation is much severe in countries, who don't have strong Institutional system of reporting and preventing domestic violence (WHO, 2020b). Some of the other reasons for increasing violence against women are: disruption in social and protective networks, additional stress of potential economic consequences and job loss, less contact with families and friends, disruptions in the abilities to earning, restricted movement, being locked down with abusers, and priority shifts in institutional system (United Nations, 2020; WHO, 2020a; Farid, 2020).

In correspondence with the worldwide situation, Bangladesh has also observed 64 days of national lockdown (March 26 to May 30). Educational institutions are still closed in fear of the rapid transmission of COVID-19. This emergency has affected girls' and women's rights and health in Bangladesh (Sakib \& Kamruzzaman, 2020). Some of the impacts are access to health care and nutrition services, decreasing access to antenatal and lifesaving inclusive obstetric and newborn care, reduced skill birth attendants, adolescent childbirth, lack of protection, and domestic violence. Marginalized women; female-headed household, women, and girls with disability, adolescent girl, elderly women, indigenous women and girls, women migrant worker, ready-made garment workers, women domestic worker, day laborer, transgender women, and female sex workers are the worst sufferer of this crisis (RGA, 2020).

The effect of this discriminatory situation of women during this pandemic is not a short-term problem. Women were in a lower and discriminatory position even before the onset of the pandemic. This pandemic has only exacerbated the existing inequalities and violence. The effect will be far-reaching and will diminish women and country's potency as a whole for a long time period. For this reason, it is necessary to address the situation of women as addressing a problem is the first step towards the solution of it. Addressing women's situation and its effects will help shift policy focuses on women to solve their problem. This study tried to point out how women face the consequences of the emergency in their lives. This includes aspects such as health, occupation, socio-economic and violence against women. Furthermore, aim of this paper is to provide several strategic and sector-specific guidelines for safeguarding women and girls' health and rights during this pandemic.

\section{METHODOLOGY OF THE STUDY}

The respective study is conducted based on secondary sources of relevant data. As per the widespread COVID-19 transmission, it was not secured and feasible to conduct fieldlevel data collection for primary data. Moreover, the respective review article aimed to coining sector-specific guidelines for safeguarding female populations in a developing state like Bangladesh. Hence, a rigorous review of appropriate and credible literature sources took place. Consequently, original research journal articles of alike subject matter were utilized principally to review the statusquo to receive an in-depth picture of the subject matter. National and international newspaper articles, relevant research reports from government and non-government organizations, webpages, podcasts, periodic situation reports, etc., are likewise reviewed. The authors of the study properly conceded all the ethical bindings that should be acknowledged. All the information sources for this article are scientifically referenced and accredited.

\section{FINDINGS}

\section{A. Health Impacts of Pandemic on Women}

\section{1) Effect of overwhelming health facilities on the sexual and reproductive health:}

From the beginning of the virus transmission, the healthcare system wing of Bangladesh has tried hard to cope with the emerged situation. This is affecting regular health care facilities essential for women and girls. This country already lacks the necessary health facilities for every citizen. On top of that, health care services have to divert their resources from routine health care services to emergency control services (Cousins, 2020). This has decreased the quality of health care services. However, women have some unique demand for health care services on the contrary to other people. As a result, they have faced the worst effects of this. 
Health facilities cannot provide women's essential services adequately like family planning services, safe abortion facilities, prenatal and post-natal care services, modern contraceptives, and sufficient skilled birth attendants. Because health workers, including midwives, are redeployed to treat COVID-19 patients. (Selim \& Sidhu, 2020). Furthermore, women are skipping necessary medical care for the panic of contracting COVID-19. (Cousins, 2020). This lack of access to essential health care will create unintended pregnancies, surging maternal and child death, and anxiousness and stress about fertility and family planning (Sandoiu, 2020).

\section{2) Occupational sex segregation:}

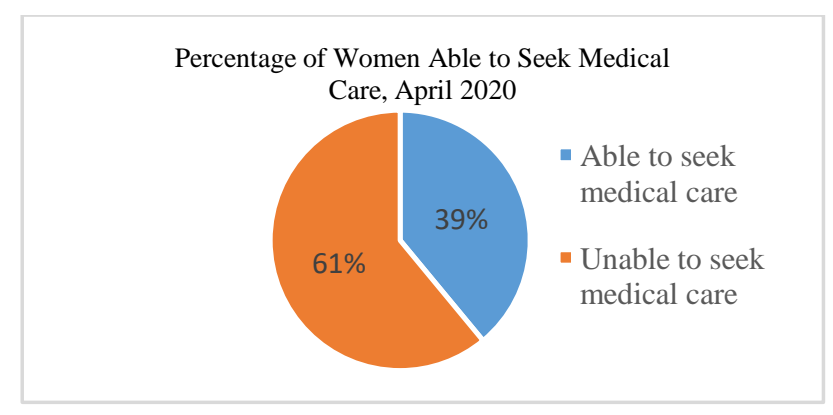

Fig. 1 Percentage of women able to seek medical care, April 2020 (Ashraf, 2020)

Globally, 70 percent of health workers and more than $94 \%$ of nurses are female. Not only that, the percentage of female community health workers is also beyond ninety. Despite these numbers, it is a matter of great regret that women's' expectations are not reflected in national or global decisionmaking process in response to the COVID-19 pandemic.

Female health workers are often required to work long hours without sick leave, low work entitlements, and underresourced conditions (RGA, 2020, United Nations, 2020). The health facilities do not provide adequate personal protective equipment for these female workers. As a result, they are at higher risk of contracting COVID-19. This work burden affects their physical and mental health to a larger extent (United Nations, 2020). Women could not seek appropriate medical care as they could not get out of the house during lockdown and confinement measures in April 2020 (Fig. 1).

It is also observed from secondary data that, number of women receiving prenatal care also decreased substantially from the number of 2019 (Fig. 2).

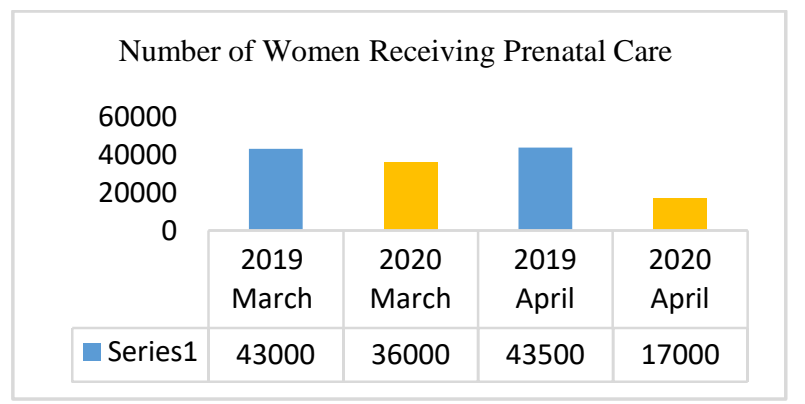

Fig. 2 Number of women receiving prenatal care (Ashraf, 2020).
Availability of skilled birth attendants is an essential indicator for safe motherhood. Similarly, the number of women giving birth in health care facilities has also decreased during this period of lockdown (Fig. 3).

\section{Numer of childbirth at health care services March-April 2019 \& 2020}

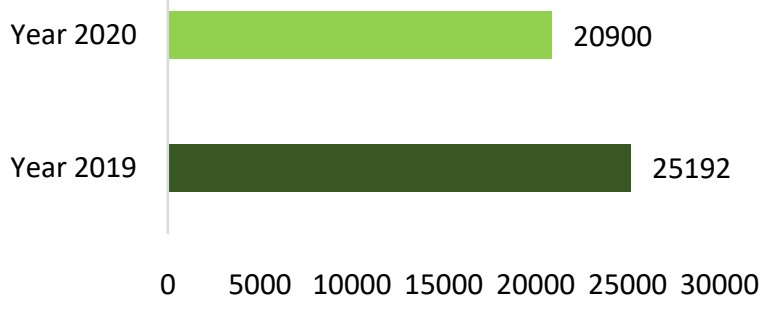

Fig. 3 Number of childbirths at health care services March-April 2019 \& 2020 (Ashraf, 2020)

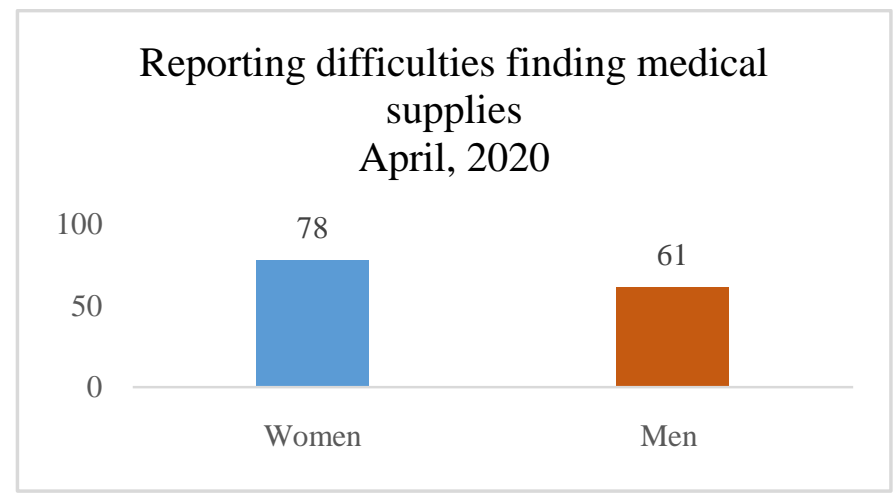

Fig. 4 Reporting difficulties finding medical supplies April 2020 (Ashraf, 2020).

Though women and men both faced difficulties receiving medical supplies, the position of women are worse than men (Fig. 4).

\section{B. Socio-Economic Impact on Woman}

The confinement process, lockdown, and quarantine adopted across the world as a response to the pandemic have drastically affected women's socio-economic condition. This is predominant in countries like Bangladesh where women are already in an inferior position in comparison to men (RGA, 2020). In accordance with above findings, this pandemic is worsening the situation of women in several ways:

1. Restricting movement: This lockdown had restricted women's movement and community interaction (Sifat, 2020)

2. Devastating women's economic condition: The sectors dominated by women are most hardly hit by covid-19 pandemic such as; teaching, tourism, retail, restaurants, hospitality, Ready-made garments factory. For this, women are most likely to suffer economically. For instance, three-quarters of the garment workers (up to 85 
$\%)$ of the garment workers are women in Bangladesh. When factories and retail stores had been closed due to pandemic, these female workers are more likely to lose their income (Burki, 2020, World Bank, 2017). Women have a lower level of earning, saving and more likely to hold insecure jobs. Their ability to cope up with economic disturbance is lower than that of men (Farid, 2020).

3. The additional burden of care work: Due to the lockdown and other preventive measures, women have to face the burden of additional care work for their families. They have to cut off their jobs (United Nations, 2020). Before the COVID-19 pandemic, women worked 3.43 times more in unpaid care work than men on average in Bangladesh (BBS Gender Statistics, 2018). Due to the closure of schools and all the family members staying at home, women are burdened with more care work than ever. That includes emotional care and administrative support for adults, cooking, cleaning, and taking care of health (RGA, 2020).

4. Social exclusion and stigmatization: Due to lockdown and preventive measures, girls are likely to drop out of school (Farid, 2020). This will hinder their prospective for accessing income generation activities, social networks, social exclusion, and stigmatization. This will also affect the existing high rate of early marriage. Furthermore, this puts girls at higher risk of torture, gender-based violence, and child labor. (Burki, 2020).

\section{Violence Against Women}

One of the worst effects of COVID-19 pandemic emergency response on women is the accelerating rate of domestic and intimate partner violence. The lockdown process does not only possess a disproportionate burden of care workers on women but also for that; women are facing an increasing amount of violence from the members of their own family (Farid, 2020). Women are now forced to stay in their homes with their abusive intimate partners with congested homes, substance abuse, restricted access to services, and diminishing peer support. (Farid, 2020; UN, 2020)

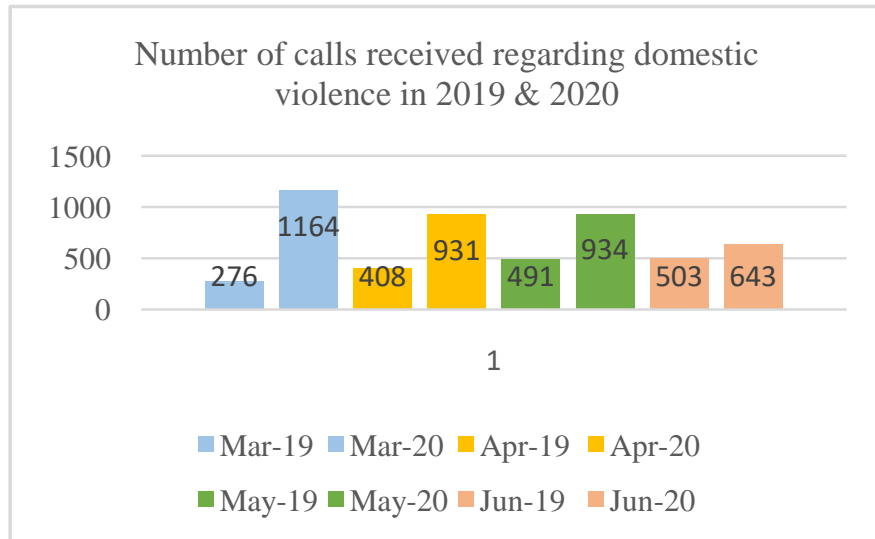

Fig. 5 Number of calls received regarding domestic violence in first six months of the year 2019 and 2020 in national emergency hotline 999 (Source: Daily Prothom Alo, 2020)
In response to domestic violence, the number of calls received by the National emergency service have also increased from 2019 (Fig. 5).

Table I: Trend of Violence against Women in March and April This Year and 2019

\begin{tabular}{|c|c|c|c|c|c|c|c|}
\hline \multirow{2}{*}{$\begin{array}{c}\text { Type of } \\
\text { offenses against } \\
\text { women }\end{array}$} & \multicolumn{3}{|c|}{2019} & \multicolumn{3}{c|}{2020} & $\begin{array}{c}\text { Cha } \\
\text { nge } \\
\text { in } \\
\%\end{array}$ \\
\cline { 2 - 7 } & Mar & Apr & Total & $\begin{array}{c}\text { M } \\
\text { ar }\end{array}$ & Apr & Total & \\
\hline $\begin{array}{c}\text { Human Rights } \\
\text { Violation } \\
\text { Incidence } \\
\text { (HRVI) }\end{array}$ & 111 & 228 & 339 & $\begin{array}{c}21 \\
5\end{array}$ & 363 & 578 & 71 \\
\hline $\begin{array}{c}\text { Violence } \\
\text { Against Women } \\
\text { and Children } \\
\text { (VAWC) }\end{array}$ & 97 & 198 & 295 & $\begin{array}{c}17 \\
8\end{array}$ & 268 & 446 & 51 \\
\hline $\begin{array}{c}\text { Violence } \\
\text { Against Women } \\
\text { and Girls } \\
\text { (VAWG) }\end{array}$ & 93 & 162 & 255 & $\begin{array}{c}17 \\
2\end{array}$ & 259 & 431 & 69 \\
\hline
\end{tabular}

(Saltamarch et al., 2020)

Violence against women shows an upward trend from 2019 due to the emergency response of pandemic (Table 1).

\section{Safeguarding the Health of Women and Girls}

1) Concern about critical healthcare services: During emergencies, infrastructure, supplies, and health workforce can be impaired or non-existent. The shift in the priority of health care service creates a challenging environment to deliver good quality key health care services. Likewise, addressing the COVID-19 emergency is disrupting the critical health services for women and girls. (WHO, 2018a). Thus, immediate steps should be undertaken for preserving regular health care services essential for women. These steps include maintaining a minimum package of these services, offering particular attention for pregnant women and maternity wards, prompting special attention for minority women as they are at higher risk of cutting off these services, and offering virtual counsel and telemedicine options, including providing access to 24-7 hotline services through health care and social service organization. Such as the hotline 109 for violence against women, which helps women report violence against them (World Bank, 2020; Viveiros \& Bonomi, 2020; Plan International UK, 2020).

2) Giving critical concern to women and girls' unique situation of health: The demand for health care is different for women and girls. Amid restrictions on movement, sustained access to a full range of high-quality care should be ensured. Some additional attention to menstrual hygiene management for women and girls, contraceptive needs and abortion facilities, safe deliveries, and pre- and post-natal care for women should be provided (Save the Children, 2020).

3) Exclusive care for women's mental health: It is crucial to look after women's mental health in accordance with physical health (Viveiros \& Bonomi, 2020). In the period of lockdown, women are facing burdens that are exaggerating their mental 
health. So, women's mental health should be taken care of by encouraging the family to share their burden of work together and counseling family to spend leisure time together by advocating counseling of women through online services and engaging creative and relaxing activities with social networking services.

\section{4) Safeguarding the rights of women and girls}

- Contract tracing and addressing the number of cases is one of the most important steps to improve the coronavirus pandemic. In this way, addressing the disproportionate burden on women and violence against them is the most critical step to improve this situation (Save the Children, 2020).

- Public and private sectors need to create a social media platform for women for reporting any kind of inappropriate treatment with them (work burden, violence; physical and mental),

- Women should be encouraged to talk about their problems by making the local community stronger in response to violence against women and building the emergency hotline more active and accessible for women.

- Continuous analysis of the differential effect of covid-19 should undergo. Social scientists and researchers can play an essential role by addressing how the pandemic and consequent lockdown affects women and girls differently than men. They can show how and in which sectors they are facing deprivation the most. In this way, they can help the policymaker take the necessary course of action to prevent discrimination against women and girls.

\section{E. Alleviating the Gendered Mishaps: The Plausible Way Out}

\section{1) Adopting multi-sectorial approach:}

- Governments and policymakers must fund, identify, and include essential services for violence against women in their emergency preparedness and response plan for COVID-19 (WHO, 2018b).

- Health facilities should address the women and girls affected by violence and provide information about the services available locally such as; hotline, shelter, counseling, rape crisis center and provide them with those services. (WHO, 2020b). Also, health facilities should use social safety nets for providing these support services to women (Guterres, 2020).

- Healthcare providers can play a vital role by offering medical treatment and first-line support. This first line supports include inquiring about needs and concerns, listening empathetically, enhancing safety, validating survivor's experience and feelings, and connecting them to support services (WHO, 2020a). Besides, improved support should be provided for women who are working in the frontline of the pandemic. They should be exempted from the "second shift" at home (Gul et al., 2020).
- Members of the community can provide indispensable support for women suffering from violence when the abuser is present at home. They should be made aware of the possibility of women falling prey to violence inside the home (WHO, $2020 \mathrm{~b}$ ). Faith based organizations and religious leaders can play a vital role by raising awareness among members of community in this regard. The nature of dissemination can be both online and offline.

- These organizations should deliver support for women subjected to violence. They can also gather data on reported cases of violence against women (WHO, 2020b). The humanitarian actors must also come up with campaigns, innovative programs and interventions which will cater towards women and girls' specific needs. The programs must also address the systematic barriers that captivate women and girls within invisible boundaries.

- Governments and international organizations should invest in women and girls' organizations that are working locally to deliver humanitarian assistance during times of crisis because local organizations have the contextualized knowledge, expertise, and established networks (Save the children, 2020). On the other hand, policymakers should be engaged in all sectors to listen and work with women's rights organizations at the time of formulating responses. This is necessary for the present crisis and also for the future (Linde \& Lay, 2020)

2) Providing economic empowerment and social protection: Women and girls disproportionately represent in the nonformal economy. For this reason, they have lack knowledge about their own rights and financial needs. For providing economic empowerment and social protection for women, issue-specific programs need to be created as per following.

- Gender-responsive social protection programs should be considered. These programs include cash transfers, social safety nets for women and girls' economic resilience (Save the Children, 2020). The existing social safety net programs i.e., test relief, vulnerable group feeding, employment generation program for the poor (EGPP) etc. must be further explored to see how women can be better accommodated.

- Government and policymakers can transform the inequalities of unpaid care work into a new, inclusive care economy that works for everyone.

- In addition to protection and support services, innovative solutions need to provide capacity building and escalating awareness for women and girls (World Bank, 2020). Measures should be included that can be implemented with low transaction costs. 
- Women dominated sectors such as teaching, tourism, retail, restaurants; hospitality should be targeted with new methodologies and supports.

- Women's network and civil society organizations can be used to communicate about benefits in microfinance and other women-oriented business (United Nations, 2020).

3) Equal leadership and participation opportunities: Safe, meaningful, and equitable participation and leadership of women and girls should be ensured to hear about their perspective and acknowledge their needs. Women tend to form only small fractions in local, regional, and national health and governance structure. Impartial involvement is necessary for safeguarding their own rights amid the emergency situation created by the pandemic. Women can get equal participation in the decision-making process through technology and digital platform (Save the Children, 2020; Plan international UK, 2020).

4) Supporting women and girls working in the frontline of the pandemic: Women constitute $70 \%$ of the health and care industry worldwide. However, authority and wage gaps make women underpaid and in a position of lower power and swell their vulnerability in the workplace and the home. Therefore, it is one of the core parts of the response to the emergency situation that the concerned authority provides them with equal opportunity in decision making, values their work, and ensure access to personal protective equipment and other sexual and reproductive health care services (Wenham, Smith, $\&$ Morgan, 2020, Save the Children, 2020).

5) Ensuring equal rights to girls in comparison to boys and empowering adolescent girls: Considering WHO's definition of "adolescent" as individuals ages 10-19 years, response to the COVID-19 emergency situation, closure of schools and social services can deepen girls' lifelong facing gender inequalities. In this regard, Suitable measures need to be taken to keep this situation under control. These include:

- Principles of equality need to be considered in offering home-schooling and in related social messaging, which includes: sexual and reproductive health information and services, as well as adolescent-friendly messaging on prevention of Gender-based violence (Save the Children, 2020; World Bank, 2020). Boys should not get advantages over girls of intra-household allocation of schooling resources (World Bank, 2020).

- Specific measures should be taken for the most vulnerable girls, for example, girls with no access to ICTs, rural girls, and disabled girls and women (World Bank, 2020). Methods and instruments for connecting safely with services and peers remotely should be ensured.

6) Creating exceptional support for minority and refugee groups: poor, minority, geographically remote, and forcibly displaced (Rohingya population) women and girls are most hard hit by the emergency situation of the Covid-19 pandemic. The necessary measures to provide support for them amid the emergency situation are the care and economic support, technical cooperation and rapid, flexible, additional and grant funding, the introduction of new or rapid expansion of existing social protection (Plan International UK, 2020), increasing access to water and soap in displaced and refugee camps, and providing hygiene and menstrual health kits (Plan International UK, 2020).

\section{F. Collaborative Efforts in Gender Sensitization}

The world has to fight the global pandemic through international and regional cooperation, information sharing, and solidarity. This will ensure a well-coordinated response that protects people in all parts of the globe. Bangladesh needs to work actively with bilateral and multilateral actors, international NGOs. This will create a principled, joined up, and gendered, need-based humanitarian response to an appropriate scale (Plan the international UK, 2020). The pandemic of women's deprivation is much more severe than the pandemic of infectious disease as the prior one is repulsing the improvement of women's lives from the dawn of civilization. So, these programs need to be continued even after the end of the pandemic, and newer ways need to be invented for adopting in the new world and ensuring women's health and rights. One of the most important things about collaboration or new interventions is that it must ensure the participation of men and boys too. Lack of sensitization and orientation about the structural and systematic barriers that women and girls face on a routine basis led men and boys to do what they do in general. The shackles of patriarchy can never be broken until and unless men and boys too start finding it toxic and undesirable.

\section{CONCLUSIONS}

Women and girls constitute nearly half of the population of Bangladesh and constitute the future potential mothers and citizens. For this reason, safeguarding their health and rights encompasses safeguarding the present and future of the country. Low level of education, minimal representation in decision making and leadership process, dominating position in the informal sector, the double burden of work, unawareness about their own rights, less integration in social safety nets, and unmet need of differential health care has already placed the life of women in a diabolical position in this country. Furthermore, this pandemic has exacerbated the situation strikingly. To this extent, Governments and policymakers ought to decidedly prioritize the need for women in this emergency situation with collaborative, strategic, and innovative ways and will have to continue this process even after the pandemic ends.

\section{REFERENCES}

[1] Ashraf, G. (2020, May 21). Lockdown in Bangladesh sees violence against women rise. Retrieved from https://en.prothomalo.com/opinion/op-ed/lockdown-inbangladesh-sees-violence-against-women-rise. 
[2] BBC. (2020, April 06). Coronavirus: The world in lockdown in maps and charts. Retrieved January 02, 2021, from https://www.bbc.com/news/world-52103747.

[3] Burki, T. (2020). The indirect impact of COVID-19 on women. The Lancet Infectious Diseases, 20(8), 904-905. doi:10.1016/s1473-3099(20)30568-5.

[4] Cousins, S. (2020). COVID-19 has "devastating" effect on women and girls. The Lancet, 396(10247), 301-302. doi:10.1016/s01406736(20)31679-2.

[5] Emelda, M. (2018, February 26). Difference Between Girls and Women. http://www.differencebetween.net/miscellaneous/culturemiscellaneous/difference-between-girls-and-women/.

[6] European Commission. (2020). Corona Virus Pandemic Impact on Gender Equality. European Union. Retrieved October 21, 2020, from

https://ec.europa.eu/info/sites/info/files/research_and_innovation/r esearch_by_area/documents/ec_rtd_covid19-genderequality_factsheet.pdf.

[7] Farid, Z. I. (2020). Experience and Perception of Urban Community Towards COVID-19 Pandemic. International Journal of Natural and Social Sciences, 7(4): 94-102. DOI: 10.5281/zenodo.4463363.

[8] Gender Statistics of Bangladesh 2018 (pp. 1-286, Rep.). (2019). Dhaka: Bangladesh Bureau of Statistics. Retrieved from https://cutt.ly/Cl0i87D

[9] Guterres, A. (2020). "Put women and girls at the centre of efforts to recover from COVID-19". Retrieved July 2, 2020, from https://www.un.org/en/un-coronavirus-communications-team/putwomen-and-girls-centre-efforts-recover-covid-19.

[10] Gul, M., Issa, S., Shikwati, 0. -, Shikwati, J., Nordmann, 2. -, Nordmann, D., . . . Hellstern, M. (2020, May 1). Covid-19 hits women harder, warns OECD. Retrieved July 2, 2020, from https://www.dandc.eu/en/article/covid-19-hits-women-harderwarns-oecd.

[11] Linde, A., \& Lay, A. (2020, May 9). What the COVID-19 pandemic tells us about gender equality. Retrieved July 1, 2020, from https://www.weforum.org/agenda/2020/05/what-the-covid19-pandemic-tells-us-about-gender-equality/.

[12] Mlađan, D., \& Cvetković, V. (2013). Classification of emergency situations. In Thematic Proceedings of International Scientific Conference "Archibald Reiss Days (pp. 275-291).

[13] Power, K. (2020). The COVID-19 pandemic has increased the care burden of women and families. Sustainability: Science, Practice and Policy, 16(1), 67-73.

[14] Plan international UK. (2020). COVID of the covid 19 crisis on girls and young women. Plan International, 1-19. Retrieved July 2, 2020, from https://plan-uk.org/file/plan-uk-coronavirus-policybriefingpdf/download?token=THR6Efm 9 .

[15] RGA. (2020, May 16). COVID-19 Bangladesh Rapid Gender Analysis - Bangladesh. Retrieved July 3, 2020, from https://reliefweb.int/report/bangladesh/covid-19-bangladesh-rapidgender-analysis.

[16] Save the Children. (2020, April 06). 8 Ways to Ensure Gender Equality Is at the Centre of Responses to COVID-19. Retrieved from https://www.savethechildren.net/blog/8-ways-ensure-genderequality-centre-responses-covid-19.

[17] Selim, F., \& Sidhu, S. (2020, June 23). Pregnant mothers and babies born during COVID-19 pandemic threatened by strained health systems and disruptions in services. Retrieved from https://www.unicef.org/bangladesh/en/press-releases/pregnantmothers-and-babies-born-during-covid-19-pandemic-threatenedstrained-health.

[18] Sandoiu, A. (2020, April 26). COVID-19: How does it affect women's sexual and reproductive health? Retrieved July 3, 2020, from https://www.medicalnewstoday.com/articles/how-covid-19affects-womens-sexual-and-reproductive-health\#Lessons-fromprevious-pandemics?
[19] Sakib, S. N., \& Kamruzzaman, M. (2020, May 31). Bangladesh reports record deaths as it lifts lockdown. Retrieved from https://www.aa.com.tr/en/asia-pacific/bangladesh-reports-recorddeaths-as-it-lifts-lockdown/1860274.

[20] Saltamarch, S. J., Sadar, S., \& Sharmin, L. D. (2020, May 21). Lockdown in Bangladesh sees violence against women rise. Prothomalo. https://en.prothomalo.com/opinion/op-ed/lockdownin-bangladesh-sees-violence-against-women-rise.

[21] Sifat R. I. (2020). Impact of the COVID-19 pandemic on domestic violence in Bangladesh. Asian Journal of Psychiatry. https://doi.org/10.1016/j.ajp.2020.102393.

[22] Tang, K., Gaoshan, J., Ahonsi, B., Ali, M., Bonet, M., Broutet, N., . . . Thwin, S. S. (2020). Sexual and reproductive health (SRH): A key issue in the emergency response to the coronavirus disease (COVID- 19) outbreak. Reproductive Health, 17(1). doi:10.1186/s12978-020-0900-9.

[23] Tarlov, A. R. (2002). Social determinants of health: the sociobiological translation. In Health and social organization (pp. 87-109). Routledge.

[24] United nations. (2020). Policy Brief: The impact of Covid-19 on Women. UN Women, 1-20. Retrieved July 2, 2020, from https://www.unwomen.org/-

/media/headquarters/attachments/sections/library/publications/202 0/policy-brief-the-impact-of-covid-19-on-womenen.pdf?la $=$ en $\& v s=1406$.

[25] UNFPA. (2020, March 26). Women, girls, health workers must not be overlooked in global COVID-19 response. Retrieved from https://www.unfpa.org/press/women-girls-health-workers-mustnot-be-overlooked-global-covid-19-response.

[26] UNFPA Bangladesh. (2020, August 17). Gender-based violence. https://bangladesh.unfpa.org/en/topics/gender-based-violence-4.

[27] Viveiros, N., \& Bonomi, A. E. (2020). Novel Coronavirus (COVID-19): Violence, Reproductive Rights and Related Health Risks for Women, Opportunities for Practice Innovation. Journal of Family Violence. doi:10.1007/s10896-020-00169-x.

[28] World Bank. (2020). Gender dimensions of the Covid-19 pandemic. World Bank Group, 1-29. Retrieved July 1, 2020, from https://openknowledge.worldbank.org/bitstream/handle/10986/336 22/Gender-Dimensions-of-the-COVID-19-

Pandemic.pdf?sequence $=1$ \&isAllowed $=y$.

[29] WHO. (2020a). 'Statement on the second meeting of the International Health Regulations (2005) Emergency Committee regarding the outbreak of novel coronavirus (2019-nCoV)', Available at: https://bit.ly/3ebBR7cv.

[30] WHO. (2020b, May 13). COVID-19 and violence against women. Retrieved July 2020, from https://www.who.int/reproductivehealth/publications/vaw-covid$19 / \mathrm{en} /$.

[31] WHO. (2018a). Primary Health Care and Health Emergencies. World Health Organization. https://www.who.int/docs/defaultsource/primary-health-careconference/emergencies.pdf?sfvrsn $=687 \mathrm{~d} 4 \mathrm{~d} 8 \mathrm{~d} \_2$.

[32] WHO. (2018b). Adolescent health. Retrieved from https://www.who.int/southeastasia/health-topics/adolescent-health.

[33] WHO, \& HRP. (2019). Violence against women Intimate partner and sexual violence against women - Evidence brief. World Health Organization. Retrieved October 21, 2020, from https://www.who.int/reproductivehealth/publications/vawevidence-brief/en/.

[34] WHO. (2021). Coronavirus disease (COVID-19). Retrieved January 04, 2021, from https://www.who.int/emergencies/diseases/novel-coronavirus2019.

[35] Worldometers. (2021). Bangladesh. Retrieved January 2, 2021, from

https://www.worldometers.info/coronavirus/country/bangladesh/.

[36] Whiting, K. (2019, March 8). 7 surprising and outrageous stats about

gender inequality. 
International Journal of Research and Innovation in Social Science (IJRISS) |Volume V, Issue III, March 2021|ISSN 2454-6186

https://www.weforum.org/agenda/2019/03/surprising-stats-aboutgender-inequality/.

[37] World Bank. (2017). In Bangladesh, Empowering and Employing Women in the Garments Sector. Retrieved from https://www.worldbank.org/en/news/feature/2017/02/07/in- bangladesh-empowering-and-employing-women-in-the-garmentssector.

[38] Wenham, C., Smith, J., \& Morgan, R. (2020). COVID-19: The gendered impacts of the outbreak. The Lancet, 395(10227), 846848. doi:10.1016/s0140-6736(20)30526-2. 